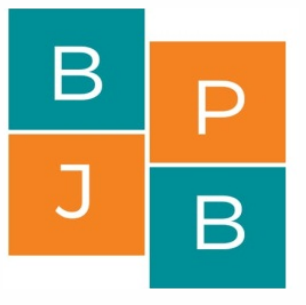

\title{
The emergence of biological problems in electronic school books (bse) class $x$ reviewed from the scientific knowledge domain of scientific literacy
}

\author{
Aa Juhanda*, Yoga Maryanto \\ Biology Education, Faculty of Teacher Training and Education, Universitas Muhammadiyah \\ Sukabumi
}

*Corresponding author: aajuhanda@gmail.com

\section{A R T I C L E I N F O}

Article history:

Received 11 September 2018

Revised 1 October 2018

Accepted 29 October 2018

Keywords:

Electronic school book, scientific

knowledge, scientific literacy.

\begin{abstract}
A B S T R A C T
This descriptive study was conducted with the aim to determine the emergence of biological problems in class XE in terms of the scientific knowledge domain of scientific literacy covering aspects of content/content, procedural and epistemic. The sample of this study consisted of 295 questions contained in the 2009 edition of BSE Biology Class X book, determined by purposive sampling technique which included examples of questions and exercises. The instrument used in this study is a document analysis document about the domain of scientific knowledge of scientific literacy. The results of the problem analysis showed that the aspect of content had the highest percentage appearance of $85.42 \%$ (excellent category) compared to the procedural aspects of $9.83 \%$ (very poor) and epistemic aspects of $1.36 \%$ (less). Based on these results it can be concluded that the domains of scientific literacy scientific knowledge contained in the class X BSE book are not balanced evenly so that the distribution of the question needs to be rearranged.
\end{abstract}

(C) 2018 Universitas Negeri Jakarta. This is an open access article under the CC-BY license (https://creativecommons.org/licenses/by/4.0)

\section{INTRODUCTION}

Indonesia's young generation in facing ASEAN Community must have literacy in various fields in order to be able to live independently in society (Liliasari, 2014). Scientific literacy is intended for all students, regardless of whether the student will later become a scientist or not (Deboer, 2000; Djamahar, et al., 2018). Scientific literacy is the ability to connect issues related to science and scientific ideas as reflective citizens (OECD, 2016, Handayani, et al., 2017). Scientific 
literacy skills are defined as a person's ability to distinguish scientific facts from various information, recognize and analyze the use of scientific inquiry methods and the ability to organize, analyze, interpret quantitative data and scientific information (Gormally, 2012, Windyarini, 2018; Ristanto, et al., 2017).

Scientific literacy is an important issue and must be addressed in Indonesia (Rizkita et al., 2016). Based on a survey conducted by TIMSS (Trends in International Mathematics and Science Study) conducted every four years in 2007 Indonesia ranked 35th out of 49 countries and in 2011 Indonesia was ranked 40 th out of 42 countries. The survey results show that the average student achievement score is below the international average score. In line with the survey conducted by TIMSS, the survey conducted by the PISA (Program for International Student Assessment) on average scientific literacy achievement scores in Indonesia is still far below the international average. In 2003 it was ranked 38th out of 40 countries, 2006 ranked 50th out of 57 countries, 2009 Indonesia ranked 60th out of 65 participants, and in 2012 it was ranked 66th out of 67 countries (OECD, 2013). In addition, the results of the PISA assessment also revealed that Indonesian students were good at memorizing concepts but not yet in the application of concepts. This can be influenced because the standard of education assessment in Indonesia itself is based on a national exam that is more identical to the assessment of the cognitive aspects of students, so that the learning carried out by the teacher focuses more on conceptual knowledge rather than understanding the concepts, processes, and context of science. Science teachers have an important role in educating students to become more literary in science. Beyond the form of education and science teachers, the material of science teaching should trigger the development of students' scientific literacy by providing balanced and representative aspects of scientific literacy.

Electronic School Books (BSE) is one type of electronic textbook designed by the Ministry of National Education (DEPDIKNAS) to be used by several schools in Indonesia. This book according to Minister of National Education Regulation No. 46 of 2007 and Number 12 of 2008 has been said to fulfill the eligibility requirements for use in the learning process at school. The breakthrough in book reform is one of the efforts made by the government in ensuring the availability of quality, inexpensive and easily accessible textbooks so that students and educators throughout Indonesia and Indonesian schools abroad can obtain and utilize good learning resources.

The existence of a test evaluation tool that includes questions in BSE is very important. Evaluation is an inseparable part of learning. Arikunto (2008) argues that evaluation in the learning process is a process to collect, analyze and interpret information to determine the level of achievement of learning objectives. As a very important part of a learning process, evaluation in the learning process should be designed and implemented by the teacher. The existence of an evaluation tool in a book can support students' abilities that will be measured through a learning process that has been done. therefore, in this study, researchers want to map the emergence of scientific literacy questions in class $\mathrm{X}$ biology in terms of the domain of scientific knowledge which includes aspects of content, procedural and epistemic knowledge.

\section{METHOD}

This research uses a descriptive method. The subjects used in this study were 295 questions contained in the 2009 edition of the BSE Biology Class X book determined by purposive sampling technique which included examples of questions and exercises. The instrument in this study used analyze document sheet about the domain of scientific knowledge of scientific literacy. The processing of test data by using the percentage formula of Arikunto (2013) as follows.

$$
\% \text { Emergence }=\frac{\sum \text { The emergence of scientific knowledge about aspects of science literacy }}{\text { All items in the books BSE }}
$$

After doing the calculation, the next step is categorization based on the Arikunto (2008) formula in table 1 . 
Table 1. Percentage Categories of Occurrence of Cognitive Levels of Bloom Taxonomy Revision on BSE Biology High School.

\begin{tabular}{cc}
\hline Percentage & Predicate \\
\hline $81-100 \%$ & Excellent \\
$61-80 \%$ & Good \\
$41-60 \%$ & Enough \\
$21-40 \%$ & Less \\
$<21 \%$ & very less \\
\hline
\end{tabular}

\section{RESULTS AND DISCUSSION}

As many as 295 questions in BSE class X have been analyzed. The results of the analysis show that the percentage value for each aspect of the domain of scientific knowledge of scientific literacy varies. The results can be presented in table 4.1 .

Table 2. Percentage of Emergence of Scienctific Literacy in Class X BSE Questions.

\begin{tabular}{llcc}
\hline $\begin{array}{c}\text { Scientific Literacy } \\
\text { Domain }\end{array}$ & Aspects of Scientific Literacy & Percentage (\%) & Category \\
\hline Scientific Knowledge & Content & 85.42 & excellent \\
& Procedural & 9.83 & very less \\
& Epistemic & 1.36 & very less \\
\hline Total Average (\%) & & 32.20 & less \\
\hline
\end{tabular}

Based on table 2, it can be seen that in the aspect of content in the domain of scientific knowledge is a very good aspect of its appearance in the problem that is equal to $85.50 \%$ and becomes dominant compared to other aspects. In this aspect, the questions presented are more demanding of students in mastering the concept and less emphasizing the competence and context of science. According to Aryani, et al., (2016) in this aspect, students' abilities are more visible in the ability to explain scientific phenomena, attract and use theories, sufficient ideas, information, and facts. Therefore, these findings support the results of the research of Firman (2007) and Mawardini, et al., (2015) which suggest that Indonesia has a low national children's scientific literacy because of its learning methods and science assessments that emphasize the dimensions of content in the form of memorization and forget about the dimensions of the process and its application in life daily. Whereas science learning must prioritize science with the conditions of competence and the context of science in real life.

In the procedural and epistemic aspects, the questions presented in the book have a very low percentage of occurrence that is equal to $9.83 \%$ and $1.36 \%$. Procedural aspects are important aspects of scientific inquiry that support the collection, analysis, and interpretation of scientific data (OECD, 2016). One can think of procedural knowledge as knowledge of standard procedures used by scientists to obtain reliable and valid data. Such knowledge is needed by both to carry out scientific investigations and engage in critical reviews of evidence that might be used to support specific claims. Meanwhile, aspects of epistemic knowledge are also needed for students. This knowledge refers to understanding the role of certain constructs and defining important features for the process of building knowledge in science (Dewi \& Ichsan, 2018; Duschl, 2007; Ichsan \& Mulyani, 2018). Students who have such knowledge can explain, for example, the differences between scientific theories and hypotheses or scientific facts and observations. Therefore, it is better for the Class X High School Biology BSE the emergence of domain scientific literacy questions in scientific knowledge must have a balanced average so that it can facilitate students to be able to master scientific knowledge well.

\section{CONCLUSION}

The emergence of domain science scientific literacy questions in BSE Biology class X shows the different mean percentages in each aspect. The aspect of science content is $85.42 \%$ 
higher than the procedural aspects is only $9.83 \%$ and epistemic aspects as much as $1.36 \%$. Therefore, there needs to be an improvement in the equity of the emergence of scientific knowledge domain scientific literacy questions that involve evaluation experts to enrich the quality of scientific literacy issues in class XE BSE.

\section{REFERENCES}

Arikunto, S. (2008). Evaluasi Program Pendidikan- Pedoman Teoritis Peraktis Bagi Mahasiswa dan Praktisi Pendidikan Edisi Kedua. Jakarta: Bumi Aksara.

Arikunto, S. (2013). Prosedur Penelitian Suatu Pendekatan Praktik. Jakarta: Rineka Cipta.

Aryani, A.K., Suwono, H., \& Parno. (2016). Profil Kemampuan Literasi Sains Siswa SMPN 3 Batu. Malang, Indonesia (pp. 847-855). Prosiding Seminar Nasional Pendidikan IPA Pascasarjana UM, Malang: Universitas Negeri Malang.

Deboer, G.E. (2000). Scientific literacy: another look st its historical ana contemporary meaning ana its relationship to science education reform. Journal of Research in Science Teaching, 37(6), 582-601.

Dewi, A. K., \& Ichsan, I. Z. (2018). Increasing junior high school student higher order thinking skills (hots) using q\&a methods in genetics topic. Proceeding of Biology Education, 2(1), 84-91. https://doi.org/10.21009/pbe.2-1.11

Djamahar, R., Ristanto, R. H., Sartono, N., Ichsan, I. Z., \& Muhlisin, A. (2018). Cirsa: designing instructional kits to empower 21st century skill. Educational Process: International Journal, 7(3), 200-208. Doi: 10.22521/edupij.2018.73.4.

Duschl, R. A. (2007). Quality Argumentation and Epistemic Criteria. Dordrecht: Springer.

Firman, H. (2007). Laporan Analisis Lietarasi Sains Berdasarkan Hasil PISA Nasional Tahun 2006. Jakarta: Pusat Penilaian Pendidikan Balitbang Depdiknas.

Handayani, G., Adisyahputra, A., \& Indrayanti, R. (2018). Correlation between integrated science process skills, and ability to read comprehension to scientific literacy in biology teachers students. Biosfer: Jurnal Pendidikan Biologi, 11(1), 22-32, doi: https://doi.org/10.21009/biosferjpb.11-1.3

Gormally, C., Brickman P., \& Lutz, M. (2012). Developing a test of scientific literacy skills (tosls): measuring undergraduates' evaluation of scientific information and arguments. CBE Life Sci Educ, 11(4): 364-377, doi: 10.1187/cbe.12-03-0026.

Ichsan, I. Z., \& Mulyani, S. W. W. (2018). Improving students' motoric skills through demonstration method in recycling plastic waste. JPBI (Jurnal Pendidikan Biologi Indonesia), 4(2), 189-194. https://doi.org/10.22219/jpbi.v4i2.5890

Liliasari. (2014). Persiapan Literasi Sains Berdasarkan Hasil PISA Nasional Tahun 2006. Jakarta: Pusat Penilaian Pendidikan Balitbang Depdiknas.

Mawardini, A., Permanasari, A., \& Sanjaya, Y. (2015). Profil literasi sains siswa smp pada pembelajaran ipa terpadu tema pencemaran lingkungan. Prosiding Seminar Nasional Fisika, 4, 49-56.

OECD. (2016). Assessing Scientific, Reading and Mathematical Literacy A framework for PISA 2015. Paris: OECD Publishing.

Ristanto, R. H. (2017). Pengembangan perangkat pembelajaran integrasi cooperative integrated reading and composition (circ) dan inkuiri terbimbing serta pengaruhnya terhadap literasi sains dan penguasaan konsep biologi mahasiswa pgsd universitas pakuan, (Unpublished Doctoral Thesis), Universitas Negeri Malang, Malang. 
Ristanto, R. H., Zubaidah, S., Amin, M., \& Rohman, F. (2017). Scientific literacy of students learned through guided inquiry. International Journal of Research and Review, 4(5), 2330.

Rizkita, L., Suwono, H., \& Susilo, H. (2016). Analisis Kemampuan Awal Literasi Sains Siswa SMA Kota Malang. Malang, Indonesia (pp. 771-781). Prosiding Seminar Nasional II Tahun 2016. Malang: Universitas Muhammadiyah Malang.

Windyariani, S. (2018). Kemampuan literasi sains siswa sd pada konteks melestarikan capung. Biosfer: Jurnal Pendidikan Biologi, 10(1), 17-21. Doi: https://doi.org/10.21009/biosferjpb.10-1.3 